\title{
Thoracic aorta aneurysm successfully operated on during pregnancy
}

\author{
Krzysztof Mokrzycki, Andrzej Biskupski, Ewelina Kuligowska, Mariusz Listewnik, Mirosław Brykczyński \\ Cardiac Surgery Department, Pomeranian Medical University, Szczecin, Poland \\ Kardiochirurgia i Torakochirurgia Polska 2014; 11 (3): 321-323
}

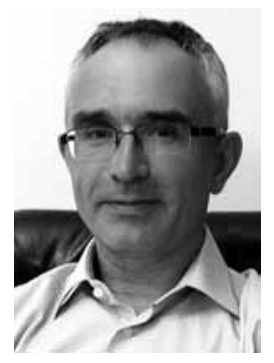

\begin{abstract}
We present the case of an asymptomatic 26-year-old female patient with a huge thoracic aneurysm discovered at a routine echo screening. The patient had previously been operated on for coarctation of the aorta in childhood and also had diagnosed bicuspid aortic valve. The operation was carried out in extracorporeal circulation at the $22^{\text {nd }}$ week of gestation without any complications. A few months later in the $38^{\text {th }}$ week of pregnancy a baby girl was delivered by cesarean section with an Apgar score of 10. The patient is scheduled for implantation of a stent graft to the descending aorta, because the CT of the chest done a few months after delivery confirmed presence of a significant aneurysm located just below the left subclavian artery.
\end{abstract}

Key words: aneurysm of aorta, pregnancy, cardiac operations.

\section{Introduction}

The rapid development of endovascular aortic repair (EVAR) techniques has greatly increased the hope for patients suffering from aortic aneurysms with a quick and non-traumatic procedure, but there is an area where there is still a crucial treatment role to be played by cardiac surgeons. Thoracic aorta aneurysms are the cause of fear to many patients as open chest surgery is still believed to be both highly risky and traumatic. The risk of such an operation is of course dependent on the type of aneurysm, patient age and coexisting diseases. Generally speaking, the younger the age, the lower the risk for the patient, quite true except in the case of pregnancy, as we have to take into account the risk to both mother and fetus.

\section{Case report}

We present the case of an asymptomatic 26-year-old woman who was referred to our outpatient clinic due to the

\section{Streszczenie}

W pracy przedstawiono przypadek 26-letniej pacjentki będącej w II trymestrze ciąży, u której rozpoznano bardzo dużego, bezobjawowego tętniaka prawdziwego aorty wstępującej. W wywiadzie - przebyta operacja koarktacji aorty w 15 . roku życia i rozpoznana dwupłatkowa zastawka aortalna. Pacjentkę zoperowano w 22. tygodniu ciąży, wszczepiając prostą protezę nadwieńcowo. Operację przeprowadzono w krążeniu pozaustrojowym z pozostawieniem dobrze funkcjonującej zastawki aortalnej. Nie stwierdzono komplikacji w okresie pooperacyjnym. W 38. tygodniu ciąży pacjentka urodziła zdrowe dziecko z 10 punktami w skali Apgar. U pacjentki zaplanowano zabieg wszczepienia stengraftów do aorty zstępującej, ponieważ badanie tomograficzne klatki piersiowej wykonane kilka miesięcy po porodzie potwierdziło obecność dużego tętniaka poniżej odejścia lewej tętnicy podobojczykowej.

Słowa kluczowe: tętniak aorty, ciąża, operacja kardiochirurgiczna.

discovery of a huge thoracic aneurysm at a routine transthoracic echocardiography (TTE) screening. The patient was at the $20^{\text {th }}$ week of pregnancy and a TTE confirmed a large aneurysm of the ascending aorta. Its diameter was $74 \mathrm{~mm}$ in TTE and $69 \mathrm{~mm}$ in intraoperative transoesophageal echocardiography (ITEE) (Figs. 1 and 2), and it began just after the sinotubular junction and ended before the aortic arch. The aortic ring, aortic bulb and sinotubular junction diameters were 24,31 and $37 \mathrm{~mm}$ respectively. Computed tomography (CT) of the chest was not done as we did not want to increase risk of fetal malformations and also due to the good quality of transthoracic echocardiography. The aortic valve was bicuspid (BAV) with a relatively good separation of leaflets and did not affect their coaptation. On the basis of the Fazel-Stanford classification proposed by Fazel and coworkers, it was cluster II of aortic dilatation in BAV [1]. The patient had previously been operated on for coarctation of the aorta in childhood (at the age of 15) with a residual pressure gradient of $20 / 10 \mathrm{mmHg}$ across the ste-

Address for correspondence: dr med. Krzysztof Mokrzycki, Cardiac Surgery Department, Pomeranian Medical University, Powstańców Wielkopolskich 72, 70-111 Szczecin, Poland, phone: +48 91466 13 93, fax: +48 91 4661393, e-mail: krzysztof.mokrzycki@pum.edu.pl 


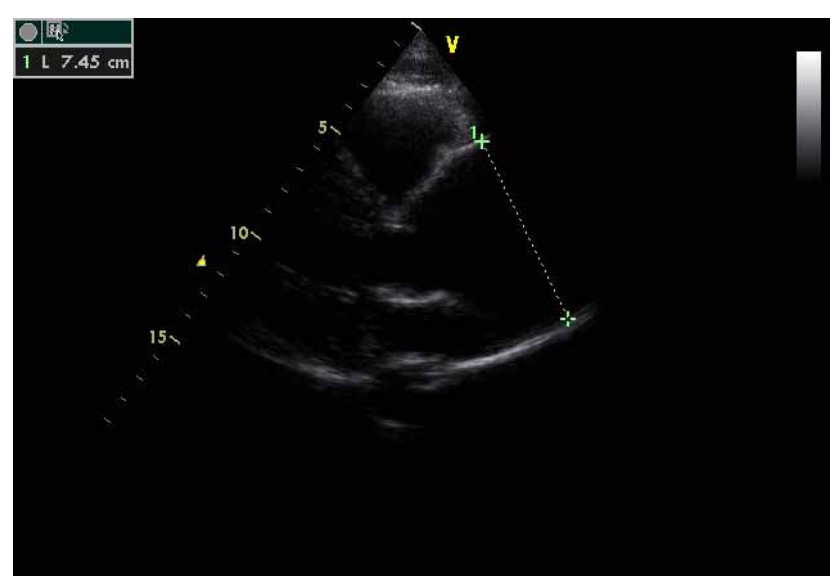

Fig. 1. Transthoracic echocardiogram. Parasternal long axis view shows diameter of ascending aorta

nosis estimated in TTE with enlargement of the descending aorta up to $44 \mathrm{~mm}$ below the isthmus shown in TEE. She was completely asymptomatic and the only reason for the visit to a cardiologist was a fear of having congenital valve disease during pregnancy. Her weight on admission was $80 \mathrm{~kg}$, height $168 \mathrm{~cm}$ and body surface area $1.68 \mathrm{~m}^{2}$. As the size of the aneurysm was huge $\left(44 \mathrm{~mm} / \mathrm{m}^{2}\right)$ with a very thin wall and the fact that it was too late to consider performing a medical abortion and too early for safe fetal delivery, we decided to operate on her during pregnancy. After a few tests before the operation the patient was admitted to hospital at the $22^{\text {nd }}$ week of gestation. The operation was carried out in extracorporeal circulation with an aortic cross-clamping time of $33 \mathrm{~min}$ and cardiopulmonary bypass time $46 \mathrm{~min}$. There were no complications during the procedure and an aneurysmectomy of the ascending aorta with supracoronary vascular prosthesis (gelatin-im-

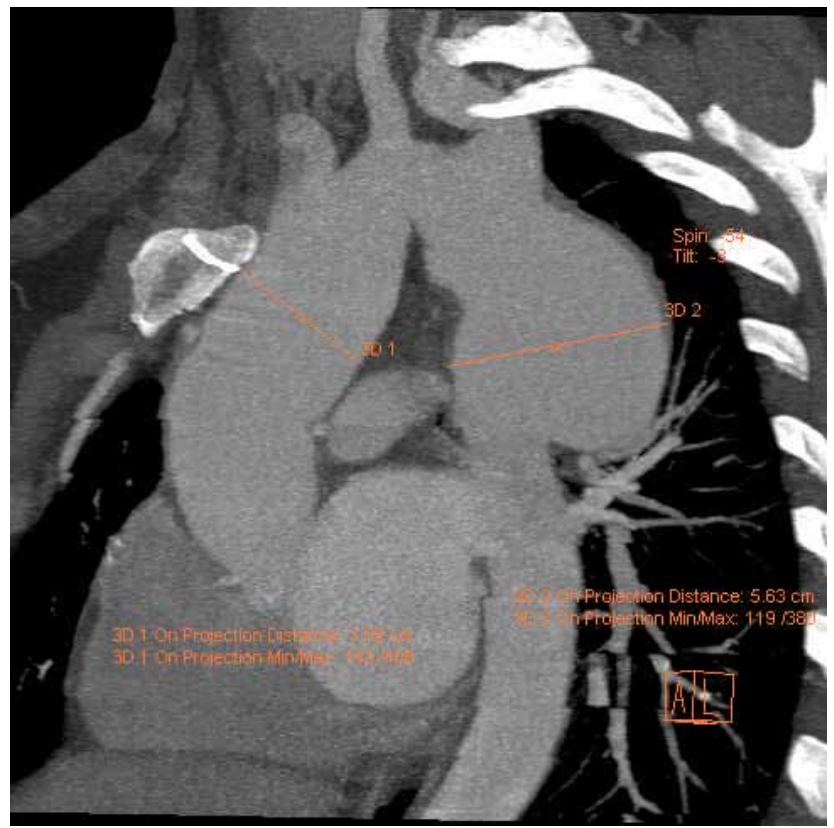

Fig. 3. Computed tomography (CT) of the chest in the frontal plane shows diameter of ascending and descending aorta

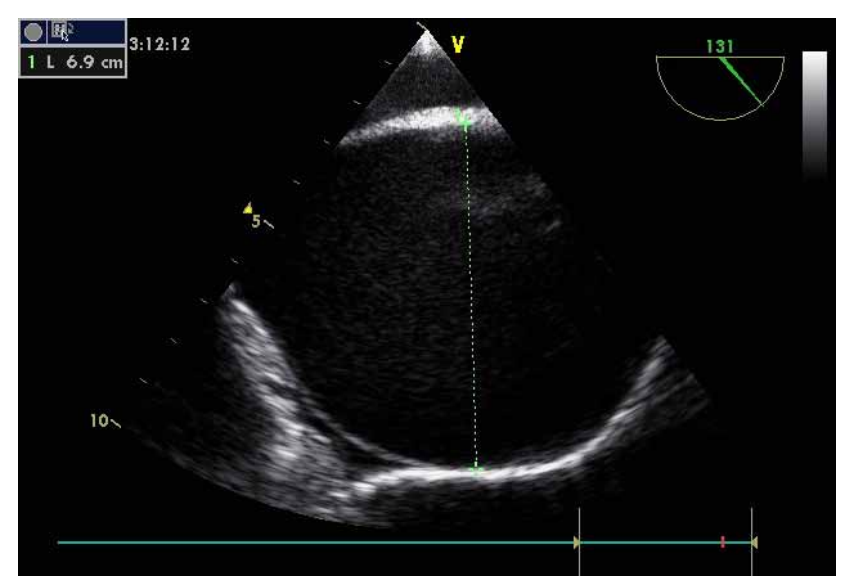

Fig. 2. Transesophageal echocardiogram. Midesophageal long axis view shows diameter of ascending aorta

pregnated knitted vascular prosthesis - Vascutek $26 \mathrm{~mm}$ ) implantation was performed. As the function of the aortic valve was good and the sinuses of Valsalva were not dilated, we limited the procedure to the ascending aorta. She did not receive any packed red blood cells, fresh frozen plasma or platelets during the procedure or postoperatively. The whole postoperative period was uneventful with the patient and the fetus showing good vital signs, which were regularly assessed by an obstetrician. She was finally transferred to the cardiology department for further observation. A few months later in the $38^{\text {th }}$ week of pregnancy a baby girl was delivered by cesarean section, with weight $3500 \mathrm{~g}$, height $58 \mathrm{~cm}$, and with an Apgar score of 10, without any visible abnormalities. The child is now developing normally, while the mother is scheduled for implantation of stent grafts to the descending aorta, as the CT of the chest done a few months after delivery confirmed the presence

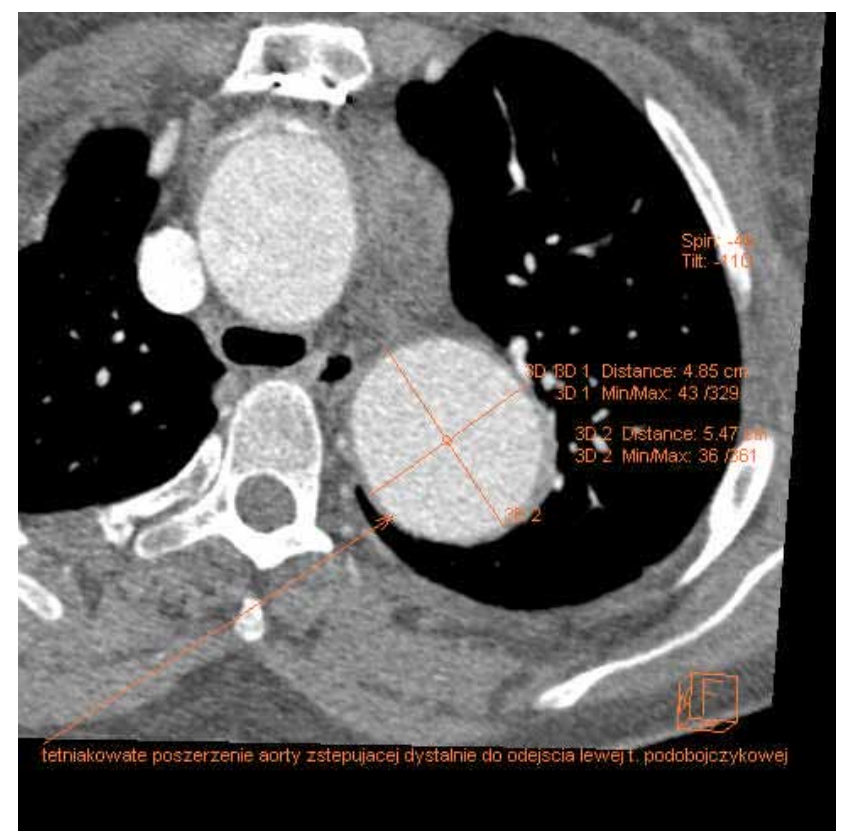

Fig. 4. Computed tomography (CT) of the chest in transverse plane shows diameter of descending aorta 
of a significant aneurysm located just below the left subclavian artery, with a diameter up to $5.6 \mathrm{~cm}$ (Figs. 3 and 4).

\section{Discussion}

The bicuspid aortic valve (BAV) is the most common congenital cardiac malformation, with a prevalence of $1-2 \%$ in the general population, causing dilatation of the ascending aorta. Other, rare causes include Marfan, Ehlers-Danlos and Loeys-Dietz syndromes, familial thoracic aortic aneurysms and dissections, and autosomal dominant polycystic kidney disease. Other less common causes are aortic aneurysms associated with Turner syndrome, neurofibromatosis, tuberous sclerosis, Noonan syndrome, osteogenesis imperfecta and homocystinuria [2]. As the probability of developing thoracic aneurysm in BAV rises with age, every woman diagnosed with this malformation should be routinely screened before planning pregnancy. A cardiac operation with cardiopulmonary bypass of a gravid patient still remains a high-risk procedure, especially for the fetus. Maternal mortality is similar to that of the nonpregnant female at $1.5-5 \%$, but as mentioned above, fetal mortality is $16-33 \%$ [3]. The decision of what should be done depends on many factors such as gestational age, type of procedure and risk of continuing pregnancy until the chances of postdelivery fetal survival are high. In our case the echocardiographic appearance of a small "dancing" heart connected to a huge aortic aneurysm by a small part of the non-dilated aortic bulb seemed to be a sign of inevitable oncoming disaster, even in a completely asymptomatic patient. Taking into consideration the size of the aneurysm and hemodynamic status of the early third trimester, the risk of fatal complications in this particular patient was very high. ESC Cardiovascular Diseases during Pregnancy (Management of) guidelines from 2011 state that "an aortic diameter index $27 \mathrm{~mm} / \mathrm{m}^{2}$ is associated with a high risk of dissection and prophylactic surgery should be considered. When progressive dilatation occurs during pregnancy, before the fetus is viable, aortic repair with the fetus in utero should be considered. When the fetus is viable, caesarean delivery followed directly by aortic surgery is recommended" [4]. We undertook actions as suggested in the above guidelines. As there is lack of randomized trials which deal with pregnant women who undergo operations on heart valves and thoracic aneurysms with cardiopulmonary bypass, each such case should be documented and published to prove or modify current guidelines. Besides that, there are a lot of cases of thoracic aneurysm in the literature, operated on just after cesarean delivery or concomitantly [5], but only a few when pregnancy was continued after a cardiovascular operation until normal term $[5,6]$.

\section{Disclosure}

The authors report no conflict of interest.

\section{References}

1. Fazel SS, Mallidi HR, Lee RS, Sheehan MP, Liang D, Fleischman D, Herfkens R, Mitchell S, Miller DC. The aortopathy of bicuspid aortic valve disease has distinctive patterns and usually involves the transverse aortic arch. J Thorac Cardiovasc Surg 2008; 135: 901-907.e2.

2. Cury M, Zeidan F, Lobato AC. Aortic disease in the young: genetic aneurysm syndromes, connective tissue disorders, and familial aortic aneurysms and dissections. Int J Vasc Med 2013; 2013: 267215.

3. Sutton SW, Duncan MA, Chase VA, Marce RJ, Meyers TP, Wood RE. Cardiopulmonary bypass and mitral replacement during pregnancy. Perfusion 2005; 20: 359-368

4. Regitz-Zagrosek V, Blomstrom Lundqist C, Borghi C, Cifkova R, Ferreira R, Foidart JM, Gibbs JS, Gohlke-Baerwolf C, Gorenek B, lung B, Kirby M, Maas AH, Morais J, Nihoyannopoulos P, Pieper PG, Presbitero P, Roos-Hesselink JW, Schaufelberger M, Seeland U, Torracca L. ESC Guidelines on the management of cardiovascular diseases during pregnancy of the European Society of Cardiology. Eur Heart J 2011; 32: 3147-3197.

5. Kinney-Ham L, Nguyen HB, Stelle R, Walters EL. Acute Aortic Dissection in Third Trimester Pregnancy without Risk Factors. West J Emerg Med 2011; 4: 571-574.

6. Tilak M, Smith J, Rogers D, Fox P, Muntazar M, Peyton M. Successful nearterm pregnancy outcome after repair of dissecting thoracic aneurysm at 14 weeks gestation. Can J Anesth 2005; 52: 1071-1075. 